\title{
ドライブレコーダーデータの効率的な自動分類手法*
}

\author{
久保 登*1, 森 みどり ${ }^{* 2}$
}

\section{An Effective Automatic Classification Method of Drive Recorder Data}

\author{
Noboru KUBO*1 and Midori MORI \\ ${ }^{* 1}$ Kanagawa University, Faculty of Engineering \\ 221-8686 Kanagawa-ken, Yokohama-shi, Kanagawa-ku, Rokkakubashi 3-27-1, JAPAN
}

Drive recorders have been used more frequently in Japan on the transportation vehicle such as taxicabs, buses and trucks than before. The drive recorders can record the driving data including motion pictures in the traffic accidents and near-accidents, which are considered as "dangerous data". Analysis and application of safety education using the "dangerous data" are useful to prevent traffic accidents. The drive recorder, however, can record a large number of "not dangerous data" which are not derived from the accident or near-accident data when the car passes the undulation or bumps on the road. The current useful method to extract the "dangerous data" exactly from all the raw data is the human observation and classification of the data while some automatic methods have been developed, which are not very exact to classify the data. The authors show a new method of automatic classification of the drive recorder data into more than two categories including "accidents", "near-accidents" and "bound" etc., by using the waveforms of the acceleration data. The method is much more effective and reliable than the current automatic methods and it enables to build an automatic processing system for mass data from drive recorders to be classified exactly.

Key Words : Transport, Safety Engineering, Data Processing, Failure Analysis, Traffic Accident, Drive Recorder, Automatic Classification, Acceleration Waveform, Standard Deviation

\section{1. は じめに}

わが国では 2005 年ごろから，事故や事故寸前のヒヤリハット時の映像・加速度データなどを記録するド ライブレコーダーが市販され，現在ではタクシー・バス・トラックなどの事業用自動車を中心に，かなりの 台数が普及している(1). ドライブレコーダーは事故の瞬間の映像を含むデータを記録するため，事故の原因 解明や当事者の過失割合の判定などにきわめて有効であり, 普及当初はドライブレコーダーを導入した多く の運送事業者の導入理由にこの目的が含まれていた(2).しかし，同時に，事故記録だけではなく，同様に記 録されるヒヤリハット記録を分析すると，事故に至る自車・他車の挙動やヒヤリハットが起きやすい道路条 件・交通状況などの特徵がわかり，事故予防対策の検討に効果的であることも期待されていた．特にタクシ 一事業者では，ヒヤリハット事例を積極的に分析し運転者教育に用い事故予防に役立てている(2)(3).そのた め，記録されたドライブレコーダー記録から簡便にヒヤリハット記録を抽出して，分析・教育に活用すること が望まれる.

現在，ドライブレコーダーには，走行中の全ての映像を記録する「常時記録型(1)」と，衝突・急ブレーキ などの衝撃・加速度を加速度センサーにより検出して（これをトリガーという）データを記録する「イベン 卜記録型」がある。おが国でドライブレコーダーが普及を始めた 2005 年ごろは，データ記録メディアの容 量が現在（2010 年）より非常に小さかったこともあって，わが国のドライブレコーダーは現状ではイベン

\footnotetext{
* 原稿受付 2011 年 1 月 28 日

${ }^{* 1}$ 正員, 神奈川大学（广221-8686 神奈川県横浜市神奈川区六角橋 3-27-1）

${ }^{* 2}$ 正員, 神奈川大学 工学部

E-mail: wtk-380bh@kanagawa-u.ac.jp
} 
ト記録型が主流を占めている.

イベント記録型のドライブレコーダーでは，事故・ヒヤリハット以外にも，乗車客発見の際の急停止，縁 石などの段差乗り越え，路面上でのバウンドなじ，特に危険ではない場面でも多数の記録が残る．トリガー 感度の設定にもよるが，著者らがデータを収集している複数のタクシー営業所（ドライブレコーダー搭載車 両数: 数十台ないし百数十台) では, 1 日 1 台当たり 1 2 件, 営業所単位では 100 200 件／日の記録が入 り，記録された全データ中の数\% 10\%程度が事故・ヒヤリハットである(4).

当事者が事象をはっきり認識している事故事例とは異なり, ヒヤリハット事例は自車運転者も発生地点や 日時を乗務後まではっきり覚えていることはほとんどない，そのため，収集したデータから事後にヒヤリ八 ットデータを抽出するには, 従来はデータ全数の映像を目視して選び出す必要があった，目視でデータを分 類する場合, 著者らの経験では 1 人 1 日 8 時間作業で 200 300 件程度が限度であり，タクシー営業所など でこの作業を行うには最低でも 1 名以上の専従職員を置かなければならず, 研究機関等の採算を度外視でき るデータ利用形態以外では, 実施困難(5)である. そのため, ヒヤリハットデータを事故予防に活用するには, 収集されたデータから自動的にヒヤリハットデータを抽出する手法が必須となる. しかし従来の手法 ${ }^{(6)(7)}$ は，十分に実用的な自動分類結果は得られなかった。

そこで本論文では，運送事業所などでのドライブレコーダーデータの活用も視野に入れ，記録されたデー タの中の加速度波形を利用して，これまで困難であった事故・ヒヤリハットデータとそれ以外のデータを的確 に自動分類する手法を示す.

また，ドライブレコーダーデータが自動分類できることによってはじめて可能となる, 応用研究や大規模な データ分析・安全指導システムの構想も併せて述べる.

\section{2. ドライブレコーダー}

\section{$2 \cdot 1$ 概要}

ドライブレコーダーには，前述のようにイベント記録式のものと常時記録式のものがある．常時記録式は 2009 年ごろから主に中国製の安価な製品として急速に出回るようになった．この方式はトリガー機構が不 要で，なおかつ事故の取りもらしがないという利点の反面，全走行時間を記録したデータから，運転者の自 覚がないような場面を事後に抽出するのが容易ではない，また，データ量が膨大になるために，全データを 保存する場合はデータ転送時間やデータ記録容量が非常に大きくなる.これに対してイベント記録式のもの は, トリガー検出機構が必要になるものの, 事故・ヒヤリハットなどのみを記録するために, データ転送時 間や記録メディアの容量を大幅に節約することができる.トリガー条件を厳しくする（大きな衝撃でないと 記録されない）と記録件数が減るので, 事後の分析が楽な反面, 事故や重要なヒヤリハットの取りもらしの 危険性が増え, トリガー条件を緩くするとこれらが逆の傾向となる. 従来は事後の分析を行う場合, 取りも らしを減らしてなおかつ記録件数をあまり増やさないような中間的なトリガー条件設定勇を行っていた.

\section{$2 \cdot 2$ データを収集したドライブレコーダー}

著者らがデータを収集したドライブレコーダーを図 1 に示寸.このドライブレコーダーは東京都内のタク シー150 台に装着されて, 通常の営業に供されている。この機械の場合, おおむね, 内蔵する加速度センサ 一の $\mathrm{x}$ 軸（左右）または $\mathrm{y}$ 軸（前後）のいずれかの加速度值が

(1) 約 $100[\mathrm{~ms}]$ の間の平均值で $0.4[\mathrm{G}]$ を超える $\left(1[\mathrm{G}]=9.8\left[\mathrm{~m} / \mathrm{s}^{2}\right]\right)$

または，x，y，z（上下）軸のいずれかの加速度值が

(2) 瞬間的に $0.5[\mathrm{G}]$ を超える 
場合にトリガーがかかるようになっている，記録されるデータは，トリガー前 10 秒・トリガー後 5 秒の合 計 15 秒間で, この間, 毎秒 30 コマのサンプリングレートで映像および加速度, 位置 (GPS データ), 速度

(トランスミッションからの速度パルスによる), 時刻, 左右方向指示器の点灯有無, ブレーキ動作（ブレ 一キ灯の点灯有無）を記録する。

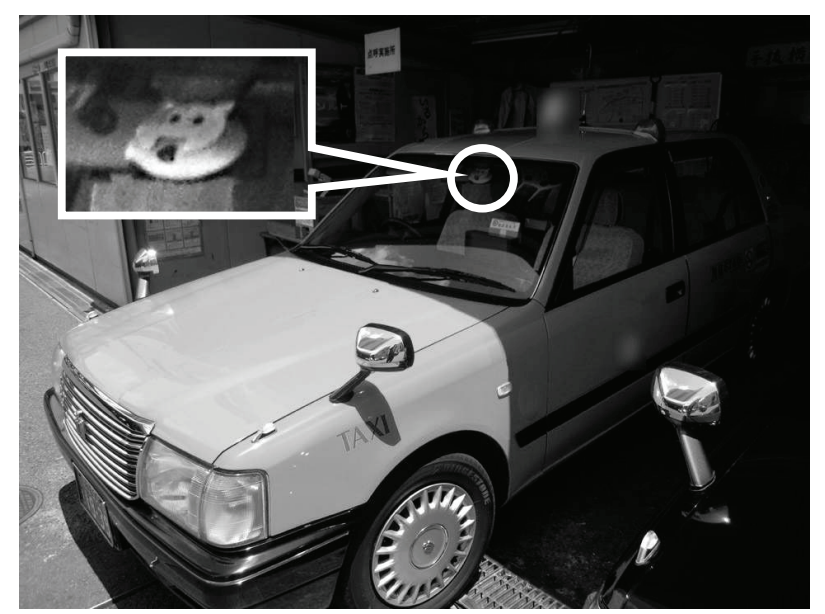

Fig. 1 The drive recorder from which the authors collected data (in the white square balloon)

ドライブレコーダーによる加速度データの波形の一例を速度変化を含めて図 2 に示す. これは, 自車が無 信号交差点に優先道路側から進入しょうとした際，左方の非優先道路（止まれ側）から減速せずに他車が横 切り，自車が急ブレーキをかけた事例である（図 3). なお, 図 2 横軸の「Frame number」は，ドライブレコ ーダーの映像の撮影コマ数で，1 コマ $($ frame $)=1 / 30[\mathrm{~s}]$ ，全 450 コマで $15[\mathrm{~s}]$ 間の記録を表す. $\mathrm{x}$ 軸加速度は 正が右方, $\mathrm{y}$ 軸加速度は正が前方, $\mathrm{z}$ 軸加速度は正が上方を示す. トリガーは設定どおり 301 コマ目（10 秒 目）でかかっているが，その付近で $\mathrm{z}$ 軸加速度が大きく負側（急ブレーキ）に変化していることがわかる. なお，図 2 のデータは車載機の動作の都合で最後の 2 秒間のデータが久落している.

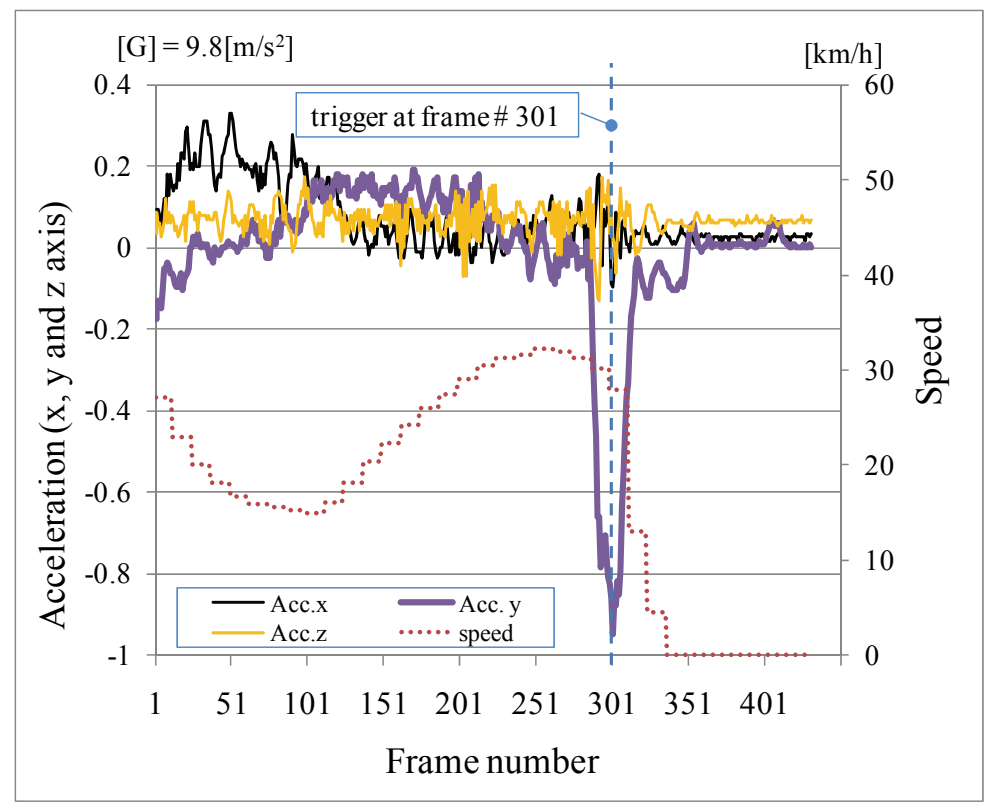

Fig. 2 An example of waveform by the drive recorder 


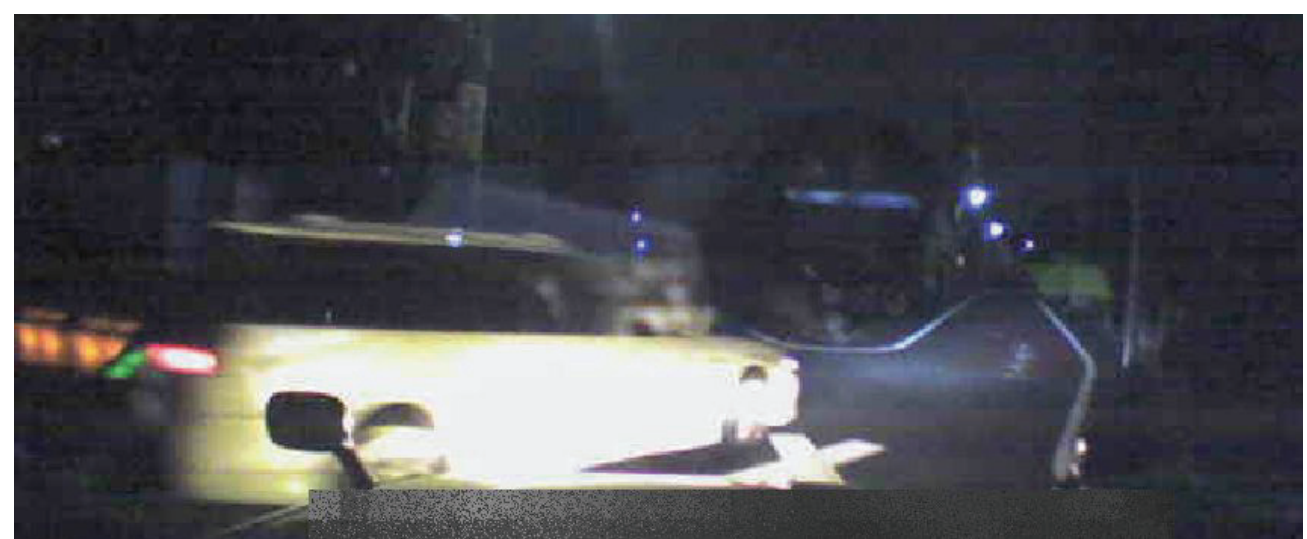

Fig. 3 The situation at a moment of the trigger outbreak in Fig. 2

(a sudden crossing by another car from the left minor road)

\section{3. 従来のデ一タ分類手法}

\section{$3 \cdot 1$ 目視による分類}

記録されたドライブレコーダーデータから，ヒヤリハット記録を抽出する最も単純な手法としては，目視 による分類がある.しかし，記録された全てのヒヤリハットを抽出するには，当然全ての記録を目視しなけ ればならない. 1 章に述べたとおり, 1 件 15 秒程度のドライブレコーダー映像を目視しながら分類する場合, 1 人 1 日 8 時間の作業時間で最大 200 件 300 件程度が限度である.このため, ドライブレコーダー搭載車 両が数十台以上あるようなタクシー営業所や, さらに大規模な事業所などでヒヤリハット記録を全数得たい 場合は，人手に頼るのでなければ何らかの自動分類方法が必須となる.

\section{$3 \cdot 2$ 指標値としきい值による分類}

従来も，ドライブレコーダーに記録された加速度センサーの波形データから，ヒヤリハット記録とそれ以 外を自動分類する手法やアプリケーションソフトウエア ${ }^{(7)}$ はいくつか存在したが, 分類成績は必ずしも良好 なものではなかった。これは, 従来の方式ではいずれも，記録されたデータから分類の基準となる「危険度」 や「切迫度」などを表す何らかの指標值と，あるしきい值を設定し，求めた指標值がそのしきい值を上回る かどうかでヒヤリハット記録かどうかを判定するためである.

指標值は, 前後方向の加速度波形の振幅や波長, 微分值（ジャーク）などを用いて, ヒヤリハット記録で は相対的に大きく, そうでないものでは小さくなるように定義することが多いが (6), 求めるべきヒヤリ八 ット記録とそれ以外の記録で指標值の大小が画然とは分かれない場合が多い. そのため, どのような值をし きい值にしても，ヒヤリハット記録の候補とそれ以外の双方に，実際のヒヤリハット記録とそれ以外の記録 が混在してしまう（図4).

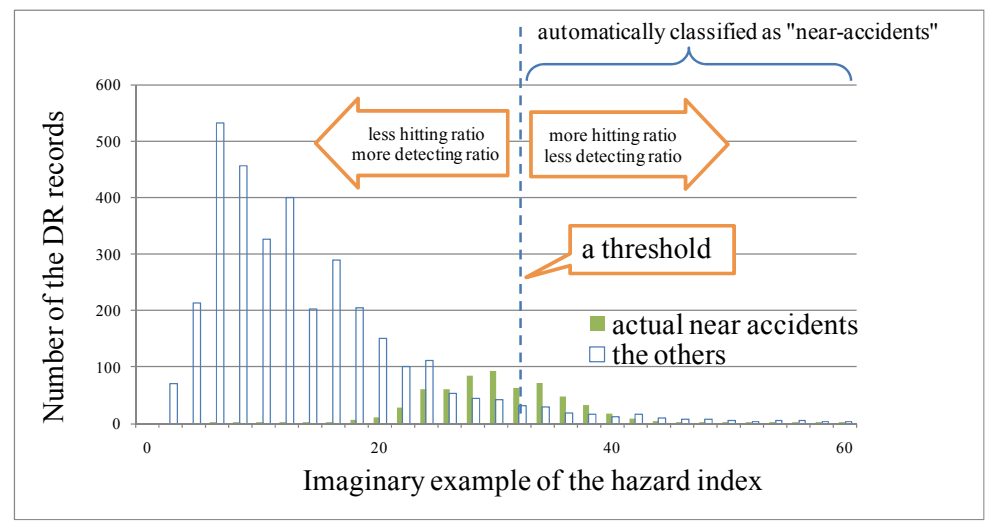

Fig. 4 Classification by a threshold 
自動分類結果の成績の指標として, 図 5 および式 1 のような「的中率 (hitting ratio) $r_{h}$ 」と式 2 のような「検 出率 (detection ratio) $\left.r_{d}\right\rfloor$ の 2 つの指標を考えることができる.

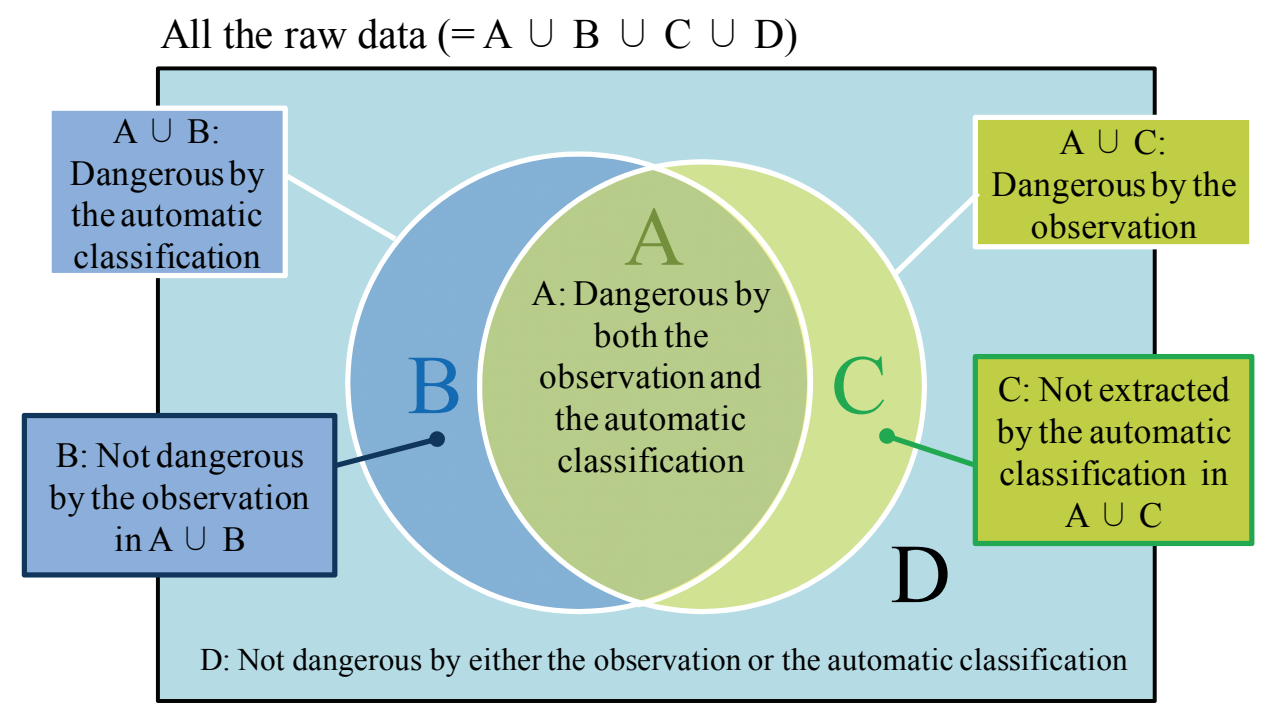

Fig. 5 The category of the observational and automatic classification results

$$
\begin{aligned}
& r_{h}=\frac{a}{a+b} \\
& r_{d}=\frac{a}{a+c}
\end{aligned}
$$

(where $a, b$ and $c$ mean the numbers of A, B and C in Fig. 5 )

的中率は, 自動分類でヒヤリハット記録と見なされたもののうち実際にヒヤリハットであったものの割合, 検出率は，実際のヒヤリハット記録のうち自動分類でヒヤリハットと見なされたものの割合である. 的中率 と検出率は，実際のヒヤリハット記録と自動分類によるヒヤリハット出力が完全に一致すれば（図 5 で B = $\phi$ かつ $\mathrm{C}=\phi), r_{h}=r_{d}=1$ とすることができる.これは実際のヒヤリハット記録とそれ以外の記録を完 全に分離できるような指標を見出すことと同值であり，理想的である．しかし，図 4 のようにヒヤリハット 記録とそれ以外の記録の指標值が画然と分かれていない場合は, 的中率と検出率はトレードオフの性質をも つようになる.たとえば，的中率を向上させたければしきい值を大きくすることになるが，検出率が小さく なってしまう（見落とされるヒヤリハット記録が多くなる凡図 5 中の $\mathrm{A} \cup \mathrm{B}$ が小さくなる）. また，逆に， 取りもらしを防ぐようにしきい值を小さくすると，検出率は大きくなるが，ヒヤリハット候補として抽出さ

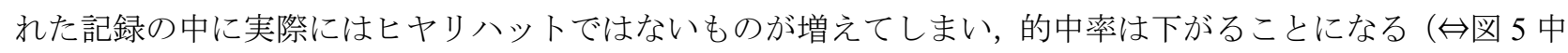
の $\mathrm{A} \cup \mathrm{B}$ が大きくなる).

なお，文献(7)の中で使用されている「漏れ率」（omission ratio $r_{o}$ ) は，上記の検出率を用いると

$$
r_{o}=1-r_{d}
$$

と表すことができる.

つまり, 的中率が大きくても検出率が小さければ, 多数のヒヤリハット記録を見逃してしまうことになり， 検出率が大きくても的中率が小さければ, ヒヤリハット候補として自動分類された記録の大部分がヒヤリ八 ットではないことになる．また，このような単一のしきい值による分類では，ヒヤリハットか否かを分類す る以外に, ヒヤリハット内の細かい分類（事故・客拾いなど）やヒヤリハット以外の分類（縁石乗り越えと 路面バウンドの区別など）をすることは全く不可能である. 


\section{4. 加速度波形の標準偏差による分類}

\section{$4 \cdot 1$ 予備的な目視分類}

そこで著者らは，従来よりも効率的にヒヤリハット記録を抽出できるような手法を考案した．本手法では， ドライブレコーダーデータのうち, $\mathrm{x}$ 軸（左右）, $\mathrm{y}$ 軸（前後， $\mathrm{z}$ 軸（上下）の 3 軸の加速度波形を利用する. まず，協力タクシー事業者から提供を受けたドライブレコーダーデータのうち 1576 件を目視分類した（表 1). 分類は以下の(1)〜(9)の基準を用いた.

Table 1 The observational classification of the 1576 actual records of drive recorders on taxicabs in Tokyo

\begin{tabular}{|c|r|r|r|r|r|r|r|r|r|r|}
\hline $\begin{array}{c}\text { (index number) } \\
\text { observational classifucation }\end{array}$ & $\begin{array}{c}\text { (1) } \\
\text { accident }\end{array}$ & $\begin{array}{c}\text { (2) } \\
\text { near- } \\
\text { accident }\end{array}$ & $\begin{array}{c}\text { (3) } \\
\text { picking up } \\
\text { customers }\end{array}$ & $\begin{array}{c}\text { (4) } \\
\text { hard } \\
\text { braking }\end{array}$ & $\begin{array}{c}\text { (5) } \\
\text { hard } \\
\text { acceleration }\end{array}$ & $\begin{array}{c}\text { (6) } \\
\text { curb }\end{array}$ & $\begin{array}{c}\text { (7) } \\
\text { buffers }\end{array}$ & $\begin{array}{c}\text { (8) } \\
\text { bound }\end{array}$ & $\begin{array}{c}\text { (9) } \\
\text { noise }\end{array}$ & subtotal \\
\hline total & 10 & 282 & 43 & 47 & 1 & 167 & 3 & 960 & 63 & 1576 \\
\hline
\end{tabular}

(1) 事故 : 他車 (者) や工作物と接触したもの

(2) ヒヤリ：事故寸前の事象，他車（者）回避のための急ブレーキなど

(3) 客拾い: 乗客を拾うために減速したもの（大部分が急ブレーキによる停車)

(4) 急ブレーキ：ヒヤリ要因が不明だが，通常より強いブレーキ（おおむ齐 $0.5 \mathrm{G}$ 以上）をかけたもの

(5) 急加速 : 通常より強い加速（おおむね $0.3 \mathrm{G}$ 以上）をおこなったもの

(6) 縁石 : U ターンや道路外（駐車場等）へ出るために, 中央分離帯・歩道縁石などを乗り越えたもの

(7) 縁石車止め: 駐車するためにバックで車止め縁石に当てたもの

(8) バウンド: 路面のうねり・段差等を通過して記録されたもの

(9) ノイズ : 記録の一部が欠けているもの，ワイパーをフロントガラスに戻した時の衝撃によるものなど

\section{$4 \cdot 2$ 各軸の加速度波形の標準偏差による分類}

次に, 1 件ごとの記録データの加速度波形について, トリガー時を中心に前後 $0.5[\mathrm{~s}]$ ずつ, 合計 $1[\mathrm{~s}]$ 間の $\mathrm{x}, \mathrm{y}, \mathrm{z}$ の各軸の加速度值（各 30 点）の標準偏差 $\sigma_{\mathrm{x}}, \sigma_{\mathrm{y}}, \sigma_{\mathrm{z}}$ を式 4 によって求める（式 4 は $\sigma_{\mathrm{x}}$ についての式， $\sigma_{\mathrm{y}}, \sigma_{\mathrm{z}}$ も 同様)、計算の中心となるフレームは正確には 287 フレーム目である。これは，データ収集に使用したドライブ レコーダーでは, 287 フレーム目に最大(*)の加速度值が記録される場合が多いことが分かったためであり，この 機種の仕様と考えられる. また， *印以降，加速度の大きさは各軸とも絶対值の大きさで考えることとする.

$$
\sigma_{x}=\sqrt{\frac{1}{n} \sum_{i=1}^{n}\left(x_{i}-\bar{x}\right)^{2}}, \quad n=30
$$

式 4 によって求めた各軸の標準偏差を, 表 1 の分類ごとに分けてグラフに表すと, 図 6 のようになった. 図 6 では，横軸に目視分類記録を上記(1)〜 (9)に分類した上で， $\sigma_{\mathrm{y}}$ （前後加速度の標準偏差 ; 図 5 中では $\mathrm{SD}_{\mathrm{y}}$ ) の值 の大きい順に並べ，各記録の $\sigma_{\mathrm{x}}\left(\mathrm{SD}_{\mathrm{x}}\right), \sigma_{\mathrm{z}}\left(\mathrm{SD}_{\mathrm{z}}\right)$ の值も同時に表示したものである. なお，以下の大小関係を見や すくするために， $\sigma_{x} ， \sigma_{y}, \sigma_{z}$ の值はそれぞれ折れ線でつないである.

図 6 を見ると, 目視分類のいくつかで $\sigma_{x}, \sigma_{y}, \sigma_{z}$ の大小関係が画然と分かれていることがわかる. 寸なわち, $\sigma_{x}, \sigma_{y}, \sigma_{z}$ のどれか 1 つが他の 2 つり卓越していて, 下式のように,
$(1) \sim(4):$
$\sigma_{\mathrm{y}}>\sigma_{\mathrm{x}}$ and $\sigma_{\mathrm{y}}>\sigma_{\mathrm{z}}$
( $\sigma_{\mathrm{y}}$ is the maximum)
(6) :
$\sigma_{\mathrm{x}}>\sigma_{\mathrm{y}}$ and $\sigma_{\mathrm{x}}>\sigma_{\mathrm{z}}$
( $\sigma_{\mathrm{x}}$ is the maximum)
(8) :
$\sigma_{\mathrm{z}}>\sigma_{\mathrm{x}}$ and $\sigma_{\mathrm{z}}>\sigma_{\mathrm{y}}$
( $\sigma_{\mathrm{z}}$ is the maximum) 
となり，「(1)事故・(2)ヒヤリハット・(3)客拾い・(4)急ブレーキ」の分類が式 5-1（以下，A 類とする）と，「(6) 縁石」が式 5-2（B 類）と，「(8)バウンド」が式 5-3（C 類）とよく対応している．そこで，本論文ではこの対応 関係を用いて自動分類アルゴリズムを構築することにした。 なお，図 6 中の「Spireness (尖塔度)」は, ノイズ データを検出するための指標であり，次章で述べる.

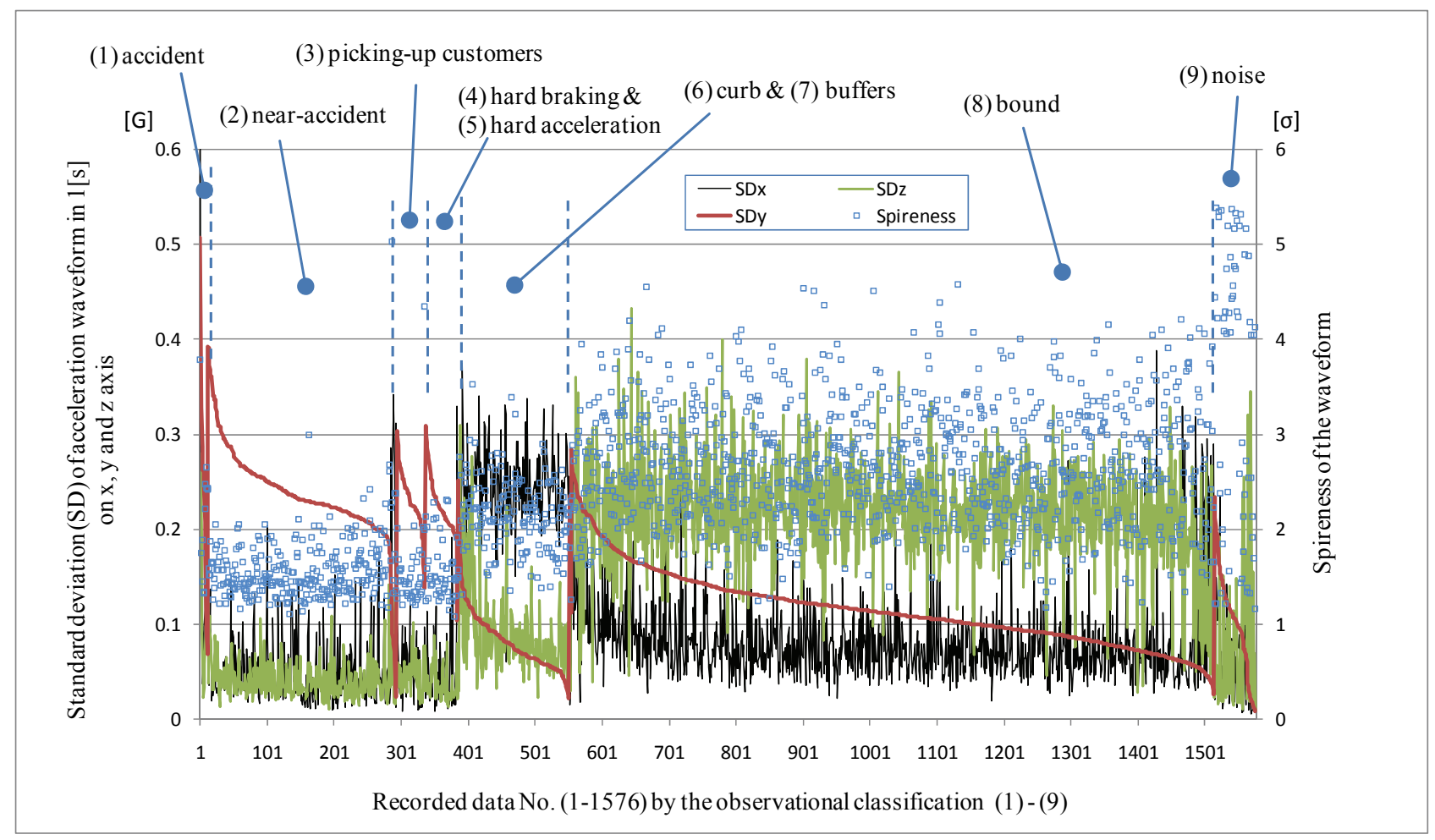

Fig. 6 Classification by the observation and the standard deviations on the $\mathrm{x}, \mathrm{y}$ and $\mathrm{z}$ axis

(1)〜(4)はいずれも急ブレーキによる加速度変化でトリガーがかかったものと考えられるが，A 類がこれに対 応するのは，急ブレーキを踏んだ場合には前後方向（y軸）の加速度変化が最も激しいためと考えられる. B 類 が縁石乗り上げに対応するのは, 縁石に乗り上げた時は左右どちらかの車輪がまず縁石の上に乗り上げて車体 がロールするので，図 1 のようにフロントガラス上部中央に取り付けられたドライブレコーダーが左右（x 軸） に最も大きく摇れるためであり, C 類が路面上でのバウンドと対応しているのは, 路面上の段差・うねり等を通 過する際には左右両輪が同時に突き上げられるので並進の上下運動またはピッチ運動が生じ，ドライブレコー ダーが上下（z 軸）に最も大きく摇れるためと考えられる.

\section{5. 補完的な分類および自動分類ソフトウエア}

\section{$5 \cdot 1$ 概要}

記録されたデータを実用的に分類するには，上記の 3 種類の分類では不十分であるので，以下に挙げるよう な波形データの特徴を基にして補完的な分類を行い，自動分類としては合計 7 種類の分類結果が得られるよう にした. 併せてこの自動分類を行うソフトウエアを製作し, 4.1 節で取り上げた実際のデータについて適用した.

\section{$5 \cdot 2$ ノイズデータ検出}

記録されたデータの中には，停車中の車両を洗車中に，立ち上げたワイパーをフロントガラスに戻した衝撃 でトリガーがかかったノイズデータも含まれる，このようなノイズデータは，スパイク上の瞬間的な加速度入 力によって記録されているので，トリガー時の $1[\mathrm{~s}]$ 間の波形が，図 7 右のような形となることが特徵である.こ 
のような波形を検出するために，トリガー時 $1[\mathrm{~s}]$ 間の 3 軸合成加速度の波形について，式 6 のような「尖塔度 (Spireness)」Sを定義した (「尖塔度」と「Spireness」は本論文の造語である).

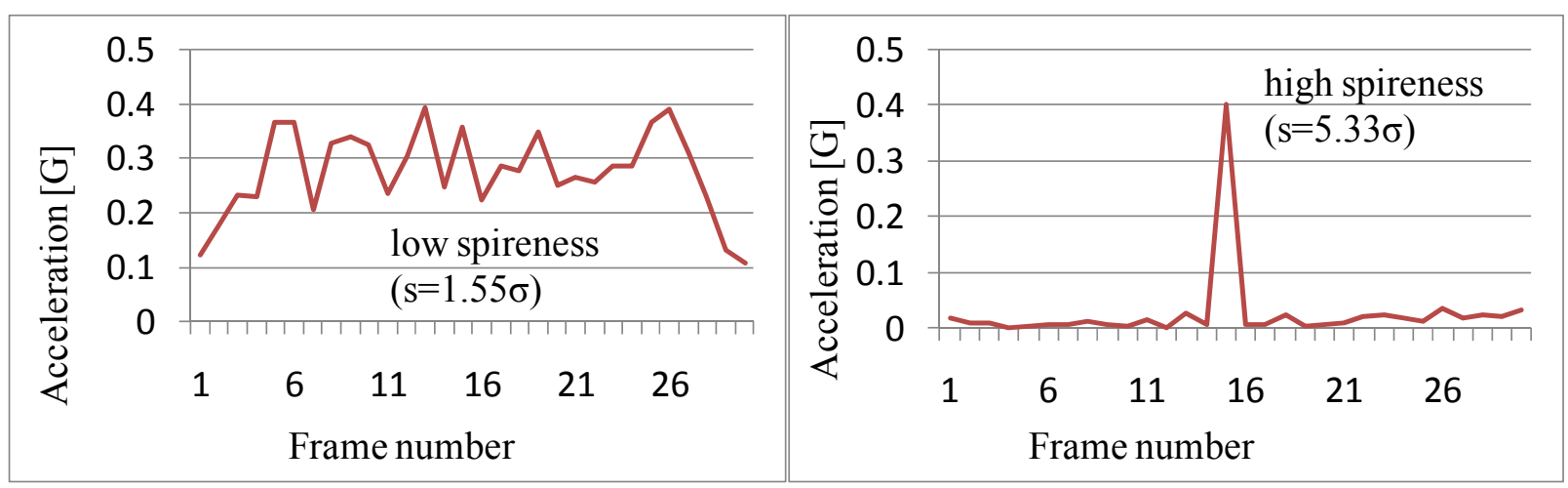

Fig. 7 Examples of low "spireness" (left) and high "spireness" (right)

$$
S=\frac{C_{M A X}-\mu_{c}}{\sigma_{c}}
$$

(ただし, $C_{M A X}: 3$ 軸合成加速度の最大值, $\mu_{C}$ : 同・平均, $\sigma_{C}$ : 同・標準偏差)

式 6 からわかるように, 尖塔度 $S$ は, トリガー時 $1[\mathrm{~s}]$ 間の 3 軸合成加速度の最大值がその間の平均值から何 $\sigma$ 離れているかを示寸指標で，正規分布における標準化変数の式そのものである.

前掲の図 6 を見ると，目視分類でノイズと判断された記録は

$$
\mathrm{S}>4
$$

となるものが多く, 式 5-1〜5-3 の判断にかかわらず, 式 7 を満たすものはノイズデータと判定することにした.

\section{$5 \cdot 3$ 事故データ検出}

同様に，記録されたデータの中には，他車との接触・衝突を記録した「事故データ」も存在する．接触・衝 突を伴わない減速では, 3 軸合成加速度の最大值が $1[\mathrm{G}]$ を超えることは少ない. これは, ブレーキによる最大の 加速度 $C_{M A X}$ は, 路面とタイヤの摩擦係数を $\mu_{o}$ とすると, 一般に

$$
C_{M A X} \leqq \mu_{o}
$$

となり, 乾燥アスファルト路面においても通常は $\mu_{o}=0.7$ 程度となるためである. 逆に, 接触・衝突をした場 合は，1[G]を大きく超える場合が多い，そこで，本手法では

$$
C_{\text {MAX }}>1
$$

の場合を接触・衝突を伴った「事故データ」とみなすことにした，ただし，5.6節に示すように，一部基準值を 変更している場合もある. 


\section{$5 \cdot 4$ 縁石車止め検出}

記録データの中には，バックで駐車スペースに入って停車する際，意図的に車止めに軽く当てて停車するも のがあった．このような事象では，トリガー時の最大加速度が $\mathrm{y}$ 軸の正の方向に現れるので，この特徵をもっ たものは，「縁石車止め」という分類とした．なお，前進して車止めに当てる場合は，衝突と区別しにくいため， 分類には含めていない.

\section{$5 \cdot 5$ 客拾い検出}

また，乗客を発見して停車する際に強いブレーキをかけた記録は，たいていの場合ハザードランプが点滅し ている．このため，上記 A 類に分類されたもののうち，トリガー作動後に短時間でも八ザードランプを動作さ せたものについては「客拾い」とみなした．また，この分類には，急ブレーキをかけ，かつ八ザードランプを 点けているが，客拾いかどうかが映像上不明確なものも含まれるので，「客または急ブレーキ」という分類名と した.

なお，目視分類にある「急加速」は，事例数が 1 例であり，一般的な特徵がつかみにくかったので，今回の 自動分類には取り入れなかった.

\section{$5 \cdot 6$ 分類手法のまとめ}

上述のように，本分類手法では，得られたドライブレコーダーデータを(1)事故・(2)ヒヤリ・(3)客または急ブ レーキ・(4)縁石・(5)縁石車止め・(6)バウンド・(7)ノイズの 7 種類に分類することができる．これをフローチャ 一トに表したものを以下に示す (図 8).

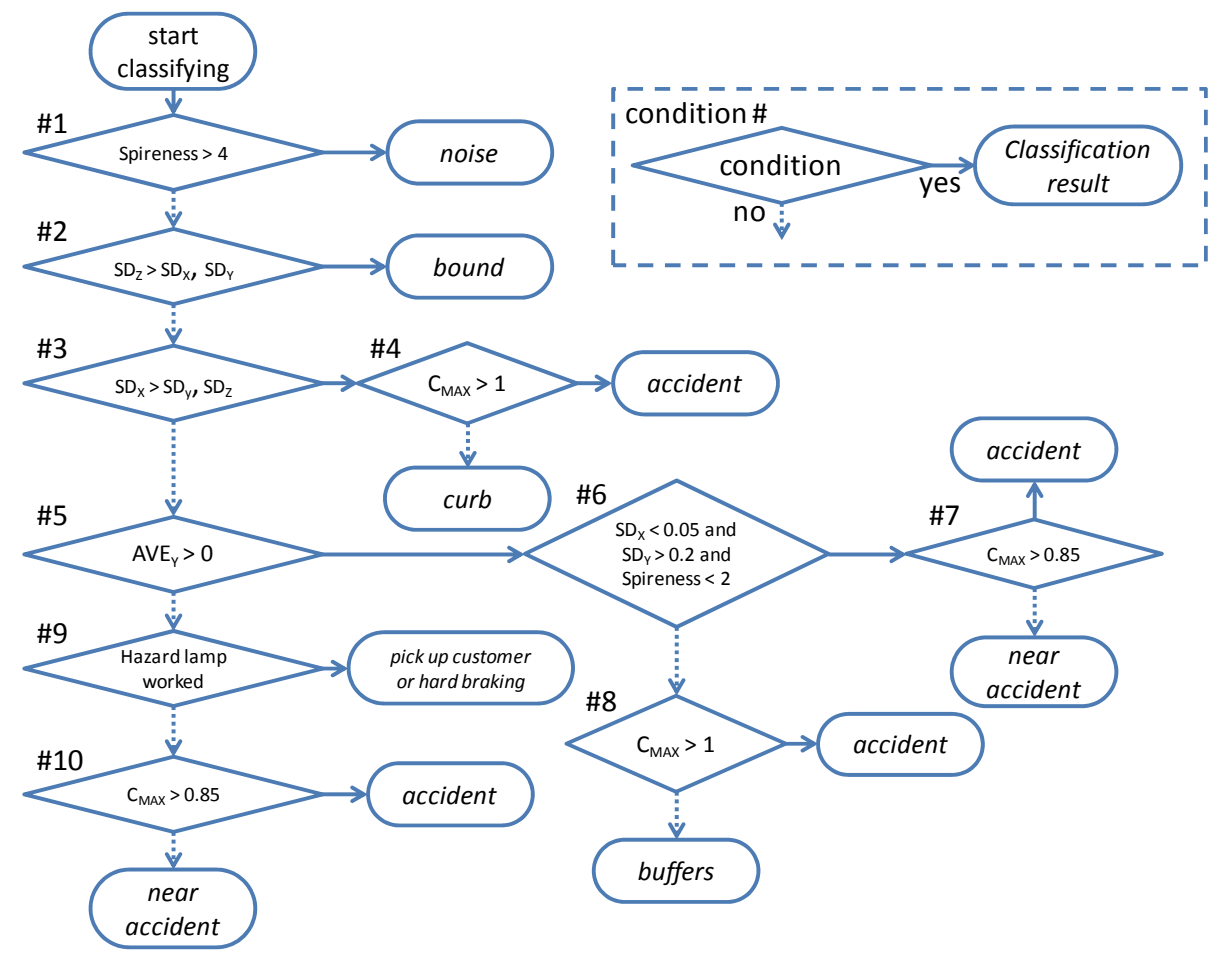

Fig. 8 The flow chart of the automatic classification method

図 8 中, 条件 6 は縁石車止め候補の中から事故・ヒヤリハット事例を再抽出するために付加的に設けたもの で，条件 7，8，10 はそれぞれヒヤリハット候補，縁石車止候補から事故事例を再抽出するために設けたもの である.これらの 4 条件はいずれも, 目視事例から, 各条件において分類に適切と考えられる条件值を設定し た（そのため，事故を抽出寸る条件として，条件 4，8 と条件 7, 10 の值が異なっている) 
また，本分類手法は，2.2 節で述べたように，使用したドライブレコーダーのトリガー条件を満たした記録の 加速度波形に適用している. そのため, なんらの選別操作も受けていない, 走行中のドライブレコーダーの加 速度センサーが検知している「生波形」に対しては，「ドライブレコーダー自体のトリガー条件」+「本手法の 分類条件」の二段階で自動分類を行っていることになる.

\section{$5 \cdot 7$ 加速度仰角}

本手法の分類は前節までに述べたが, 事故・ヒヤリハットなどに自動分類されたものが多数出力された場合, その中から切迫度が高いものを取り急いで調べたいことがある．そのため，4.2 節と同様のトリガ一時を中心と した $1[\mathrm{~s}]$ の間の最大の 3 軸合成加速度ベクトル $C_{M A X}$ が， $\mathrm{xy}$ 平面とな寸角 $\theta$ を「加速度仰角」として定義した（図 $9 \cdot$ 式 10).

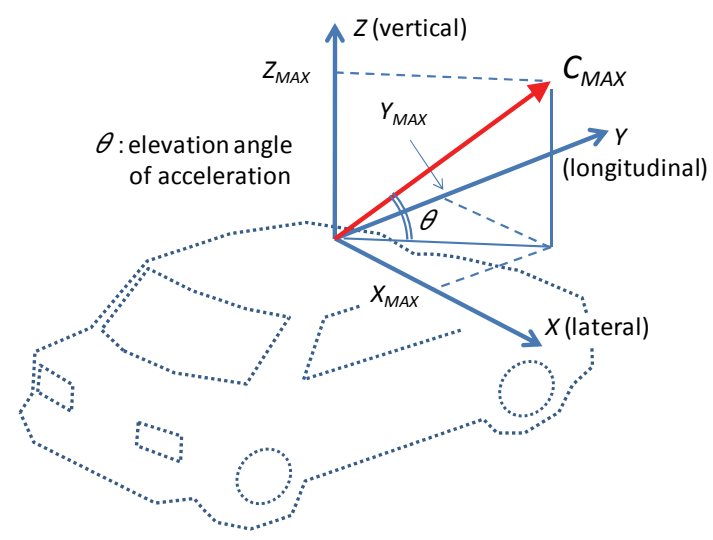

Fig. 9 The elevation angle of the acceleration

$$
\theta=\sin ^{-1} \frac{|Z|_{M A X}}{C_{M A X}}, \quad C_{M A X}=\sqrt{|X|_{M A X}^{2}+|Y|_{M A X}^{2}+|Z|_{M A X}^{2}}
$$

加速度仰角が小さいとは $C_{M A X}$ が $\mathrm{xy}$ 平面に沿っている（水平に寝ている）ことを表し，ヒヤリハットなどの危 険な記録は加速度仰角が小さい傾向がある（図 10). 図 10 では，目視分類で事故・ヒヤリハット・急ブレーキ 等に分類されたものを「danger」としている.

なお，この加速度仰角は 3.2 節で触れた「しきい值」による分類に用いるような指標の一つであるが，ここで は多数の自動分類結果から分析等に必要な記録を適宜見つけるための補助的な指標として用い，分類目的では 使用していない.

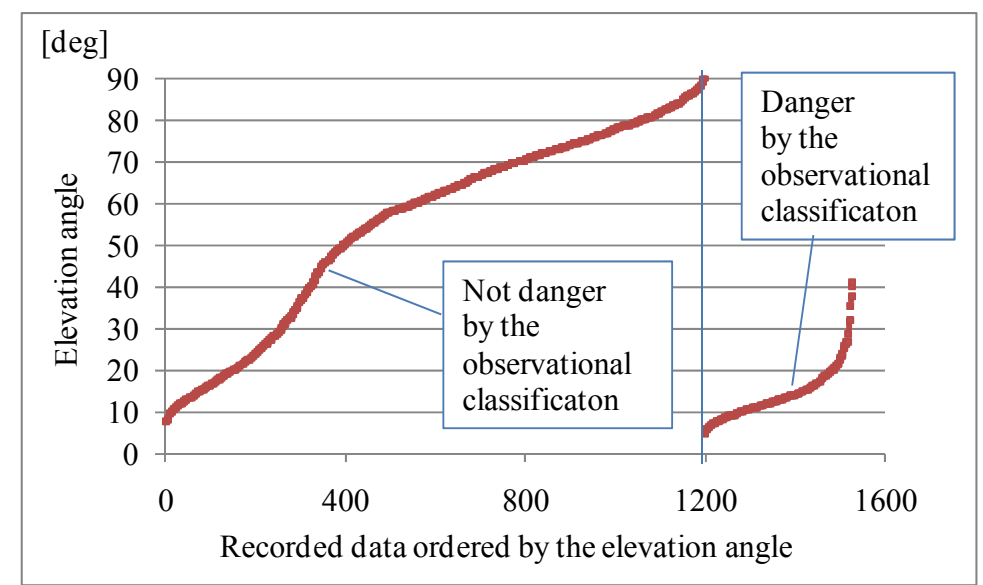

Fig. 10 The tendency of the elevation angle 


\section{$5 \cdot 8$ 本手法を組み込んだソフトウエアアプリケーションの製作}

前節までに示した分類手法を組み込み，実際のドライブレコーダーデータを自動的に処理して表示・保存す るソフトウエアアプリケーションを製作した（図 11).

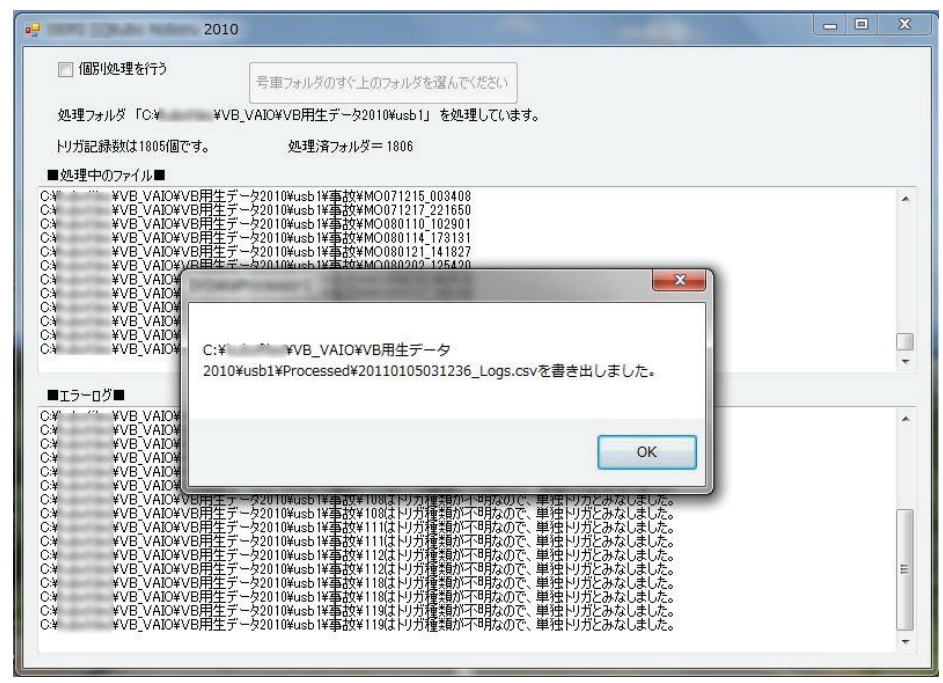

Fig. 11 Application software for the automatic classification method

処理後の出力データは，データ 1 件が 1 行の表形式となり，他の記録データ（記録日時, 記録地点，速度な ど）と一緒に表示される. 出力データには処理元データの動画へのリンクが記載されるので，見たいデータの 動画再生も容易である. また，インターネット地図への地点データリンクも記載されているので, 発生地点を 容易に特定することも可能である．計算機上で要する処理時間は，原稿執筆時点（2010 年末）の一般的なノー トパソコン（Intel Core2Duo, Windows7）で，およそ毎分 1000 件程度である.

\section{6. 自動分類結果の評価}

\section{$6 \cdot 1$ 目視分類結果との比較}

本手法を 4.1 節の目視分類データに適用した結果を表 2 に示す（表中の空欄は 0 件を示す）。表 2 を見ると， 表 1 で行った目視分類でのヒヤリハットや客拾いが自動分類でもよく検出されていることが分かる. また, 縁 石やバウンドも，よく自動分類されている．このような縁石とバウンド記録の峻別は従来では全く不可能であ ったので，特筆すべき結果と言える.

また目視分類結果を(1)〜(5)の「危険類」と(6)（9)の「非危険類」に，自動分類結果を(1)〜(3)の「ヒヤリハッ 卜候補」と(4)〜(7)の「それ以外」二分して集計した結果を表 3 に示寸．表 3 の分類は，4.2 節の A 類に属する ような急ブレーキによる記録を，危険性のある「ヒヤリハット類」とみなし， 6.3 節で述べる従来手法の自動分 類結果と比較するために設けた.

Table 2 The result of the automatic classification by the new method (the blank cell means 0 )

\begin{tabular}{|c|c|c|c|c|c|c|c|c|c|c|c|}
\hline \multirow[t]{2}{*}{ 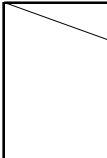 } & \multirow{2}{*}{$\begin{array}{l}\text { observational classification } \\
\text { automatic classification }\end{array}$} & \multicolumn{5}{|c|}{ dangerous } & \multicolumn{4}{|c|}{ not dangerous } & \multirow[b]{2}{*}{ subtotal } \\
\hline & & $\begin{array}{c}(1) \\
\text { accident }\end{array}$ & $\begin{array}{c}(2) \\
\text { near- } \\
\text { accident }\end{array}$ & \begin{tabular}{|c|}
$\begin{array}{c}\text { (3) } \\
\text { picking up } \\
\text { customers }\end{array}$ \\
\end{tabular} & \begin{tabular}{|c|}
$\begin{array}{c}(4) \\
\text { hard } \\
\text { braking }\end{array}$ \\
\end{tabular} & $\begin{array}{c}(5) \\
\text { hard } \\
\text { acceleration } \\
\end{array}$ & $\begin{array}{l}\text { (6) } \\
\text { curb }\end{array}$ & $\begin{array}{c}\text { (7) } \\
\text { buffers }\end{array}$ & $\begin{array}{c}(8) \\
\text { bound }\end{array}$ & $\begin{array}{c}(9) \\
\text { noise }\end{array}$ & \\
\hline near- & (1)accident & 2 & 18 & & 1 & & & & 8 & 7 & 36 \\
\hline accident & (2)near-accident & 4 & 232 & 5 & 33 & & 3 & 1 & 15 & 1 & 294 \\
\hline candidate & (3)hard braking or customers & & 11 & 34 & 11 & & & 1 & & 1 & 58 \\
\hline the & (4)curb & 4 & 7 & & & 1 & 158 & & 50 & 3 & 223 \\
\hline \multirow[t]{4}{*}{ others } & (5)buffers & & 13 & 3 & 2 & & & & 19 & 7 & 44 \\
\hline & (6)bound & & & & & & 6 & 1 & 844 & 9 & 860 \\
\hline & (7)noise & & 1 & 1 & & & & & 24 & 35 & 61 \\
\hline & total & 10 & 282 & 43 & 47 & 1 & 167 & 3 & 960 & 63 & 1576 \\
\hline
\end{tabular}


Table 3 Summed up the table 2 by "dangerous" and "not dangerous" category

\begin{tabular}{|l|r|r|r|}
\hline the new method & dangerous & $\begin{array}{c}\text { not } \\
\text { dangerous }\end{array}$ & subtotal \\
\hline near-accident candidate & 351 & 37 & 388 \\
\hline the others & 32 & 1156 & 1188 \\
\hline total & 383 & 1193 & 1576 \\
\hline
\end{tabular}

\section{$6 \cdot 2 \kappa$ (カッパ) 係数による評価}

前節の目視分類との比較を，コーエン ${ }^{(8)} の \kappa$ 係数によって評価した. $\kappa$ 係数とは，二者（ここでは目視と自動 分類）による同一事象の分類の一致度を，見かけの一致度から偶然による一致度を除いて評価したもので， $k \geqq$ 0.4 でおおむね一致, $\kappa \geqq 0.6$ でよく一致， $\kappa \geqq 0.8$ できわめてよく一致しているとみなされる. $\kappa=0$ の場合は完全 不一致, $\kappa=1$ の場合は完全一致（両者の分類が全く一致した）を表す.

本手法による自動分類結果と目視結果の $\kappa$ 係数を求めたところ, $\kappa=0.73$ (帰無仮説 $\kappa=0$ に対して有意水準 $1 \%$ で有意）であった．従って，本手法による自動分類は，目視分類との一致度が有意に高い分類を出力できると 言える. なお， $\kappa$ 係数は，二者の分類区分が同数でなければならないので，表 2 の目視区分(3), (4), (5)を一つに まとめ, 自動分類結果と同じ 7 分類とした.

\section{$6 \cdot 3$ 従来の自動分類ソフトとの比較}

国土交通省（MLIT）では，2008 年にドライブレコーダーデータの自動分類ソフトウエア (7)を公表した．この ソフトウエアは無償ダウンロードできるので, 4.1 節と同一のデータをこの自動分類ソフトウエアで処理した. この結果を表 4 に示す．このソフトウエアは，3.2 節で述べたしきい值方式で，しきい值を強(tight), 弱(loose) の 2 段階に変えることができる. 強の場合は的中率が高いが検出率は低く, 弱の場合はその逆の傾向となるこ とが文献(7)に記載されている．表 4 を見ると，強・弱いずれの場合も，ヒヤリハット候補以外とみなされるデー タが非常に多いことが分かる.

Table 4 The result of the automatic classification software by MLIT (upper: tight condition, lower: loose condition)

\begin{tabular}{|c|c|c|c|c|c|c|c|c|c|c|}
\hline automatic & $\begin{array}{c}(1) \\
\text { accident }\end{array}$ & $\begin{array}{c}(2) \\
\text { near- } \\
\text { accident }\end{array}$ & $\begin{array}{c}\text { (3) } \\
\text { picking up } \\
\text { customers }\end{array}$ & $\begin{array}{c}\text { (4) } \\
\text { hard } \\
\text { braking }\end{array}$ & $\begin{array}{c}\text { (5) } \\
\text { hard } \\
\text { acceleration }\end{array}$ & $\begin{array}{l}\text { (6) } \\
\text { curb }\end{array}$ & $\begin{array}{c}(7) \\
\text { buffers }\end{array}$ & $\begin{array}{c}(8) \\
\text { bound }\end{array}$ & $\begin{array}{c}(9) \\
\text { noise }\end{array}$ & subtotal \\
\hline near-accident candidate & 3 & 22 & & 3 & & & & & 3 & 31 \\
\hline the others & 7 & 260 & 43 & 44 & 1 & 167 & 3 & 960 & 60 & 1545 \\
\hline total & 10 & 282 & 43 & 47 & 1 & 167 & 3 & 960 & 63 & 1576 \\
\hline
\end{tabular}

\begin{tabular}{|c|c|c|c|c|c|c|c|c|c|c|}
\hline automatic $\quad$ obsevational & $\begin{array}{c}\text { (1) } \\
\text { accident }\end{array}$ & $\begin{array}{c}(2) \\
\text { near- } \\
\text { accident }\end{array}$ & $\begin{array}{c}\text { (3) } \\
\text { picking up } \\
\text { customers }\end{array}$ & $\begin{array}{c}\text { (4) } \\
\text { hard } \\
\text { braking }\end{array}$ & \begin{tabular}{|c|}
$(5)$ \\
hard \\
acceleration
\end{tabular} & $\begin{array}{l}\text { (6) } \\
\text { curb }\end{array}$ & $\begin{array}{c}(7) \\
\text { buffers }\end{array}$ & $\begin{array}{c}(8) \\
\text { bound }\end{array}$ & $\begin{array}{c}(9) \\
\text { noise }\end{array}$ & subtotal \\
\hline near-accident candidate & 4 & 71 & & 8 & & & & 1 & 3 & 87 \\
\hline the others & 6 & 211 & 43 & 39 & 1 & 167 & 3 & 959 & 60 & 1489 \\
\hline total & 10 & 282 & 43 & 47 & 1 & 167 & 3 & 960 & 63 & 1576 \\
\hline
\end{tabular}

国土交通省ソフトウエアの分類結果を表 3 と同様に「危険」・「非危険」の 2 分類とした集計を表 5 に示す. またこの 2 分類集計について, 抽出率 (extraction ratio) • 的中率 (hitting ratio) •検出率 (detection ratio) とその定義, および本論文の手法との比較を表 6,7 に示寸．表 7 には, 国土交通省ソフトウエア結果について 6.2 節に示し た $\kappa$ 係数も求め, 本手法と比較した，なお，抽出率とは，入力した生データ数に対して，ヒヤリハット候補と して自動的に認識されて出力されたデータ数の割合である. 的中率・検出率は 3.2 節で定義したものと同じ意味 である. 
Table 5 Summed up results of MLIT software

\begin{tabular}{|c|c|c|c|}
\hline MLIT (tight) & dangerous & $\begin{array}{c}\text { not } \\
\text { dangerous }\end{array}$ & subtotal \\
\hline near-accident candidate & 28 & 3 & 31 \\
\hline the others & 355 & 1190 & 1545 \\
\hline total & 383 & 1193 & 1576 \\
\hline
\end{tabular}

\begin{tabular}{|l|r|r|r|}
\hline \multicolumn{1}{|c|}{ MLIT (loose) } & dangerous & $\begin{array}{c}\text { not } \\
\text { dangerous }\end{array}$ & \\
subtotal \\
\hline near-accident candidate & 83 & 4 & 87 \\
\hline the others & 300 & 1189 & 1489 \\
\hline total & 383 & 1193 & 1576 \\
\hline
\end{tabular}

Table 6 Definitions of extraction ratio, hitting ratio and detection ratio

\begin{tabular}{|l|c|c|c|}
\hline & dangerous & $\begin{array}{c}\text { not } \\
\text { dangerous }\end{array}$ & subtotal \\
\hline near-accident candidate & $\mathrm{a}$ & $\mathrm{b}$ & $\mathrm{c}$ \\
\hline the others & $\mathrm{d}$ & $\mathrm{e}$ & $\mathrm{f}$ \\
\hline total & $\mathrm{g}$ & $\mathrm{h}$ & $\mathrm{i}$ \\
\hline
\end{tabular}

\begin{tabular}{|l|l|}
\hline extraction ratio $\%$ & $100 * \mathrm{c} / \mathrm{i}$ \\
\hline hitting ratio $\%$ & $100 * \mathrm{a} / \mathrm{c}$ \\
\hline detection ratio $\%$ & $100 * \mathrm{a} / \mathrm{g}$ \\
\hline
\end{tabular}

Table 7 The three evaluation ratios and kappa coefficient for the new method and MLIT classification

\begin{tabular}{|l|r|r|r|}
\hline evaluation ratios & $\begin{array}{r}\text { methods } \\
\text { method }\end{array}$ & $\begin{array}{c}\text { MILT } \\
\text { (tight) }\end{array}$ & $\begin{array}{c}\text { MLIT } \\
\text { (loose) }\end{array}$ \\
\hline extraction ratio\% & 24.6 & 2.0 & 5.5 \\
\hline hitting ratio\% & 90.5 & 90.3 & 95.4 \\
\hline detection ratio\% & 91.6 & 7.3 & 21.7 \\
\hline$\kappa$ coefficient & 0.88 & 0.10 & 0.29 \\
\hline
\end{tabular}

これによれば，国土交通省ソフトは的中率を上げるために抽出率を下げた（しきい值を非常に高くした）の で，的中率は非常に高いが，検出率がきわめて低くなってしまっている．言い換えれば，最もヒヤリハットデ 一タが集まり，それ以外のデータがほとんど混ざっていない「上澄多部分」の最上部のみをすくっていること になる。これに対して本論文の手法はしきい值によらない分類方法を用いて, きわめて高い的中率と検出率を 両立している. さらに, 表 7 の 2 分類集計の場合の $\kappa$ 係数は $\kappa>0.8$ （有意水準 $1 \%$ で有意）であり，自動分類と 目視結果が極めてよく一致していることが分かる.

\section{7. 本手法の応用}

\section{$7 \cdot 1$ 目視分析の代替}

本手法における自動分類結果は， 6.2 節に示したように，目視分析の代替手法として十分に用いることができ る. このため, 従来困難だった多数の車両から収集される大量のドライブレコーダーデータを自動で振り分け ることができ, ヒヤリハット分析やその結果を利用した安全教育において, 飛躍的に効率を向上させることが できる.

\section{$7 \cdot 2$ バウンドおよび縁石の検出}

本手法では, 路面上のうねりや段差から生じるバウンドと, 道路外に出るための縁石乗り上げなどをそれぞ れ的確に検出することができる.これは従来手法では一律に「ヒヤリハット候補以外」(「ゴミデータ」・「不要 データ」などと呼ばれることもある）として分類されていた記録群である.このため,「バウンド」からは，こ の記録の集中地点を見ることで道路面状態の適否などを，「縁石」からは歩道設備の状態や，運転者の運転行動 （U ターンによる中央分離帯縁石の乗り越え）などを検討することができる. 


\section{$7 \cdot 3$ 記録集中地点の検討}

本手法を用いると，ヒヤリハット事例やバウンド事例，縁石事例などが自動的に多数収集できるので，従来 は非常に手間のかかった特定の分類の「記録集中地点」の検出が容易になる. これを検討することで，事故に つながる恐れのある交通環境などの調査が進展する. 図 12 は，6.1 節の自動分類結果において，バウンド記録 の集中地点のうちの 1 ケ所を図示したものである.このようにバウンド記録が集中していることは，この地点 の路面上に何らかの段差や起伏等があるものと考えられる。これらの記録のドライブレコーダー映像および現 地観察からこの地点は実際に工事中であり，路面起伏があることが分かった（図 13）.

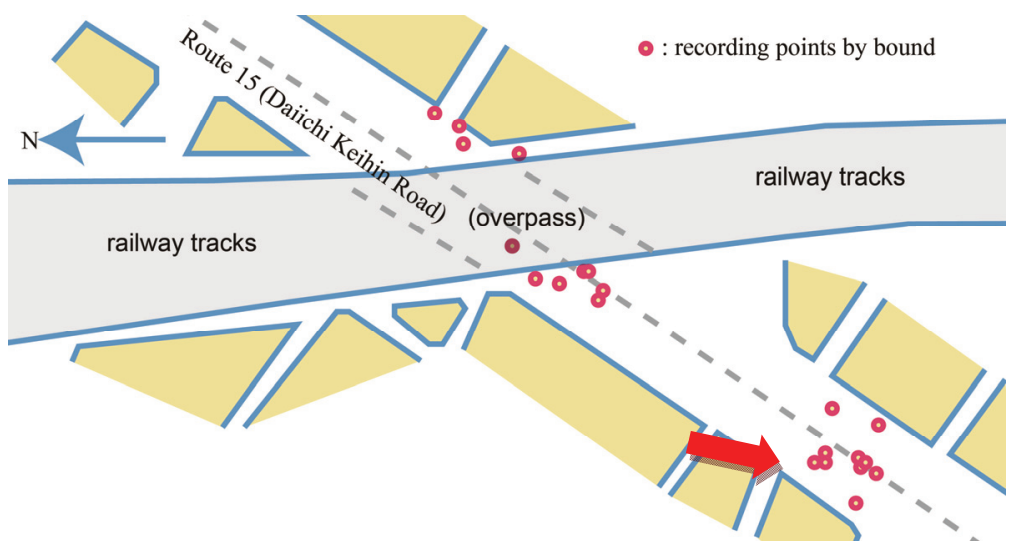

Fig. 12 A concentration of the recording points by bound

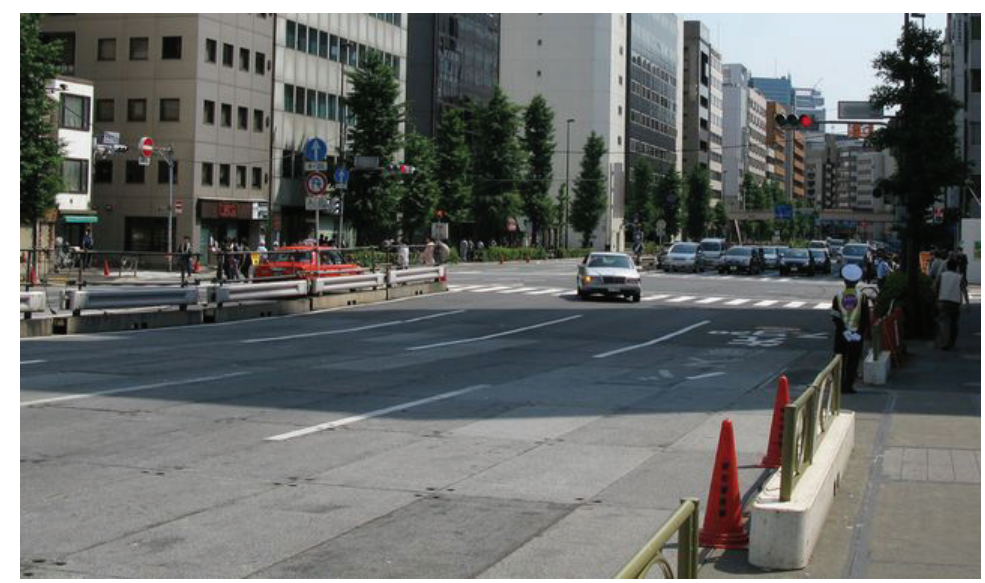

Fig. 13 Actual situation of the concentration point in Fig. 13 (taken from the red allow)

\section{$7 \cdot 4$ 大規模データセンターの構築}

わが国のドライブレコーダーは，本論文に利用しているものなど，多数の車両からのデータを無線 LAN 等で 一括して収集できるもの ${ }^{(5)}$ が存在する。このようなドライブレコーダーシステムを用いると，運送事業者などが 所属車両の全てのドライブレコーダーデータを 1 ケ所に転送し, 自動的に分類・集計・分析を行って, 事業所・ 営業所・運転者の安全教育に資寸ることができる. 数百両以上の車両が所属するような運輸事業者の営業所で は，毎日 1000 件以上のドライブレコーダーデータが蓄積されることも珍しくないので，このようなドライブレ コーダー運用形態では, 本論文のような自動分類手法は必須のものとなる.

また, 著者らはすでに, タクシ一営業所で一括収集されたデータを分析場所（著者らの研究室）一自動転送 するシステムを試作運用している(9).これらを発展させ，データセキュリティを確保しながら複数の運送事業者 のデータを蓄積・分析する「大規模データセンター」を構築すれば，全国的な交通安全性向上に画期的な役割 を果たすことが期待できる（図 14）。このようなシステムでは, 本論文で開発したデータ自動分類技術は, 文字 通りの中核技術となる。 


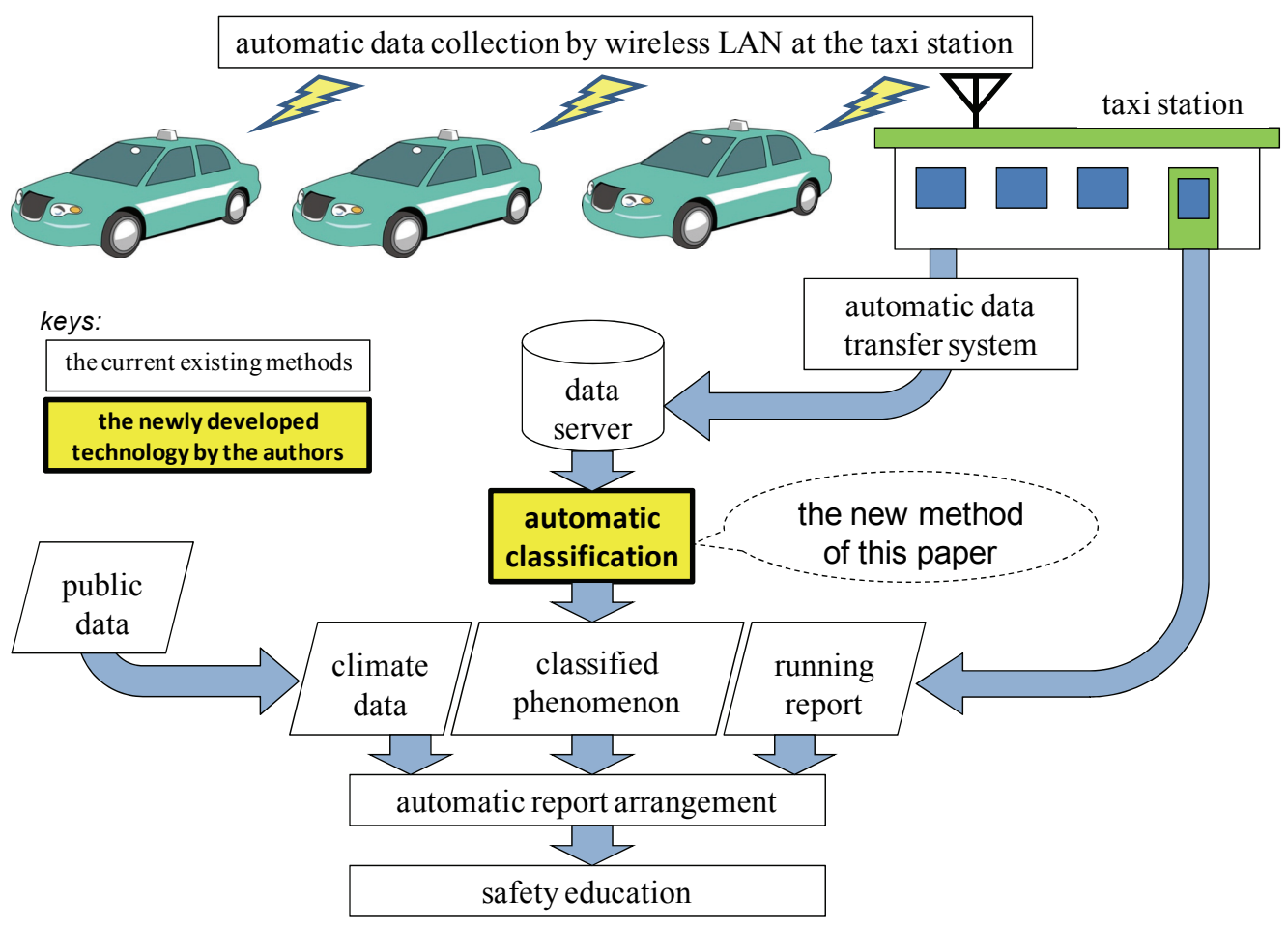

Fig. 14 A structure of the central processing system of the drive recorder data

\section{8. 課 題}

\section{$8 \cdot 1$ 分類性能の向上}

本論文での自動分類手法は，従来手法に比べれば格段に目視分類との一致性が高いが， 1 割程度の誤判断が残 る．今後はこれをなるべく少なくするようにすればさらによい．

\section{$8 \cdot 2$ A 類の詳細分類}

4 章で定義した $\mathrm{A}$ 類に分類される事象は，事故，ヒヤリハット，急ブレーキ，客拾いなど，本来はさらに詳 細に的確な分類をしたい事象が混在している．現状では，4.4節および 4.5 節の分類により事故と客拾いを区分 けしているが，この分類をさらに目視結果に合致するようにした上で，追突形態，出会い頭事故形態，歩行者・ 自転車の飛び出し形態などもある程度分類できるようにすれば，さらに利用価值が高まる．今後，種々の事故・ ヒヤリハット形態における加速度波形の特徴を精査し, このような詳細な分類も行えるようにする予定である.

\section{9. ま と め}

本論文では，車両に搭載したドライブレコーダーから収集される記録データを，加速度波形の標準偏差を用 いることによって的確に自動分類する手法について述べた．このような高効率な自動分類手法はこれまで全く 類を見ないものである. 本手法を応用することによって, 実路を走行する多数の車両からの走行状態・事故七 ヤリハット発生の状況などを自動的に分類・分析できるようになり，事故詳細分析 ${ }^{(10)}$ ・事故防止・安全教育・ 道路環境整備などへの応用可能性が飛躍的に高まることが期待できる.

\section{謝 辞}

本研究においては, 神奈川大学工学部・堀野定雄准教授, 神奈川大学 工学研究所 高安心超安全交通研究所・ 龍重法客員研究員, 石川博敏客員研究員に多大なご協力とご助言を頂いた. ここに深い謝意を表す. 


\section{文献}

(1) 荒井紀博, “ドライブレコーダの動向”, 自動車研究, Vol. 32, No. 2 (2010), pp. 5-8.

（2）国土交通省自動車交通局，“平成 17 年度映像記録型ドライブレコーダ活用モデル事業調查報告書”, (2006).

（3）国土交通省自動車交通局，“平成 18 年度映像記録型ドライブレコーダ活用モデル事業調査報告書”, (2007).

（4）堀野定雄，森みどり，久保登，小澤聡，依光健，荒川義之，島田淳也，“映像記録型ドライブレコーダを用いた夕 クシー事故・ニアミス解析と予防安全”，日本人間工学会誌第45巻特別号(2009), pp. 276-277.

(5) 久保登, 北島創, 龍重法, 石倉理有, “効果的なドライブレコーダデータ収集と解析システムの構築”, 自動車研 究, Vol. 27, No. 11 (2005), pp. 19-22.

(6) 今長久, 北島創, 鷹取収, 荒井紀博, “ドライブレコーダで記録される事故・ニアミス映像を安全運転学習に活 用するためのデータ判別ソフトウェアの作成”，自動車研究，Vol. 31, No. 9 (2009), pp. 29-34.

（7）国土交通省自動車交通局，“平成 19 年度映像記録型ドライブレコーダ活用モデル事業調查報告書”, (2008).

(8) Cohen, J., "A coefficient of agreement for nominal scales". Educational and Psychological Measurement, Vol. 20 (1) (1960), pp. $37-46$.

（9）久保登，榎田修一，荒川等，石川正士，岩崎宣仁，堀之内新吾，林豊洋，龍重法，石川博敏，森みざり，堀野定 雄, “東京のタクシー車両に搭載されたドライブレコーダーのデータ自動収集システムの構築”, 自動車技術会 2010 年秋季大会学術講演会前刷集 No. 98-10 (2010), pp. 5-10.

(10) 久保登, 堀野定雄, 森みどり, “ドライブレコーダー映像を用いた事故詳細分析”, 自動車技術会 2010 年春季大 会学術講演会前刷集 No. 18-10 (2010), pp. 17-20. 